\title{
A-D TYPOLOGY OF TV VIEWERS
}

We can distinguish the types of TV viewers in quantitative (capacity of viewing) and qualitative (activity/passive) aspects, and their synthesis (A-D types of TV viewers).

We documented the dominance of television and radio in cares of 595 adolescent respondents.

Practical possibility of using of A-D TV viewers types (and differentiation of TV viewers by capacity of viewing or their activity/passive) has approved.

\section{Introduction}

We don't think about real influence of mass media communication very often. But we let the television in the centre of our households, it takes away a lot of time. It is an extension of cognition and entertainment. On the other hand television can more or less (un)critically form our thinking, personality. There is a reciprocal impact of media reality to reality of real world.

\section{The typologies of $\mathrm{TV}$ viewers}

The types of TV viewers are derived from two access methodologies: quantitative (for example cultivation theory) and qualitative (for example theory of selective exposure).

G. Gerbner and his colleagues [1] distinguish TV viewers with quantitative high level of TV viewing (heavy viewers) a TV viewers with quantitative low level of TV viewing (low viewers). J. R. Dominick [1] describes 7 hours a day of TV viewing in average household, 3 hours for each person a day. S. M. Livingstone [7] indicates that children view television about 19 hours a week. J. M. Innes a H. Zeitz [2] speak about 0-9 hours a week for low viewers, 10-19 hours a week for average viewers and more than 20 hours a week for heavy viewers.

A. Nociar [11] describes $39.7 \%$ of adolescent respondents view television or video from 1 to 2 hours a day, $42.0 \%$ from 3 to 4 hours and $12.0 \% 5$ hours a day and more. But M. Mikuláštík [10] says Czech children view television from 6 to 8 hours a day. Of course, there is an increase of TV viewing during weekend. S. A. Lowery a M. L. De Fleur [8] think TV viewing is from 0.5 to 1 hour a day longer during weekend. We suppose [4] heavy TV viewers view television more than 27 hours a week (4 and more hours a day), low viewers view television 14 and less hours a week (2 and less hours a day).

\footnotetext{
* Daniel Kotrč

Faculty of Science, University of Zilina, E-mail: daniel.kotrc@fpv.uniza.sk
}

We can suppose activity or passivity of TV viewers. Theory of selective exposure confirms Festinger's theory of cognitive dissonance. TV viewers try to keep clear of information in conflict with older one. F. Biocca in Littlejohn [6] discusses five characteristics of the active audience:

1. selectivity - active audiences are considered to be selective in the media they choose to use;

2. utilitarianism - active audiences are said to use media to meet particular needs and goals;

3. intentionality - implies the purposeful use of media content;

4. involvement or effort - audiences are actively attending, thinking about and using the media;

5. belief to be impervious to influence.

\section{The A-D typology of TV viewers}

We combined quantitative Gerbner's cultivation theory [3] and qualitative Biocca's theory [6] of selective exposure and we obtained A-D types of TV viewers, Schema 1.

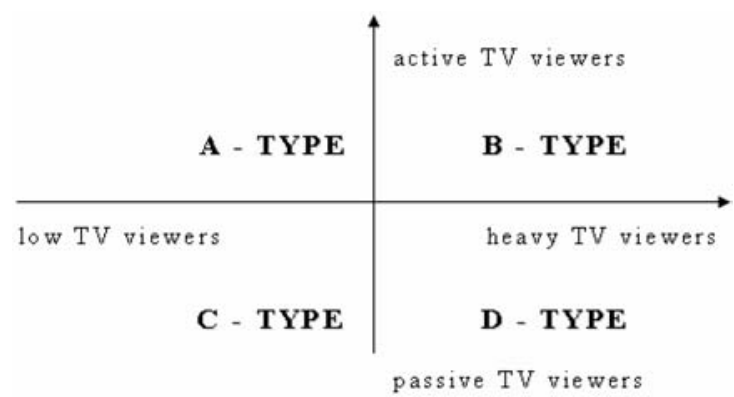

Schema 1: A-D types of TV viewers

$A$ - TYPE: low and active TV viewers

$B$ - TYPE: heavy and active $T V$ viewers

$C$ - TYPE: low and passive TV viewers

$D$ - TYPE: heavy and passive $T V$ viewers 


\section{Research of the A-D typology of TV viewers}

We tried to verify the approach of original typology of A-D types of TV viewers and differentiation of TV viewers by capacity of viewing or their activity/passive. The research analysed the types of TV viewers in relation to preferred programme structure specifications.

Sample. We realized individual consultations with 4 psychologists. Then we realized the pre-research with 15 university students of social work. The main research includes 595 adolescent respondents, 237 boys (39.8\%) and 358 girls (60.2\%). Respondents were from all kinds of secondary schools. We realized administration of the research battery with psychologists from pedagogical-psychological offices (Kysucké Nové Mesto, Banská Bystrica, Košice, Žilina and Zlaté Moravce).

Method. The research battery consisted of the Questionnaire of relation to television and television programme. The Questionnaire of relation to television includes:

- time of using (newspapers and magazines, radio, television, video and internet) and preferred programme structure;

- preference of violence programmes;

- activity;

- dependence on television.

Administration was realized during the same three days. Respondents marked TV programmes of the same previous week.

Results. We documented the dominance of television and radio in cares of respondents. The respondents viewed television 3.3 hours a day during weekend and 2.6 hours a day from Monday to Friday; mean: 2.8 hours a day. Adolescent girls viewed television more than adolescent boys (only tendency), Table 1 .

Differences between adolescent boys and girls

Table 1 depending on mass media used

\begin{tabular}{|c|c|c|c|c|c|c|c|c|c|}
\hline \multirow{2}{*}{ mass media } & \multicolumn{3}{|c|}{ boys } & \multicolumn{3}{|c|}{ girls } & & & \\
\hline & $\mathrm{n}$ & $\mathrm{AM}$ & SD & $\mathrm{n}$ & AM & SD & $t$ & df & p \\
\hline newspapers and magazines & 237] & 83 & 76 & 354 & 1.01 & 78 & -2.749 & 589 & .006 \\
\hline radio & 237 & 3.97 & 4.20 & 354 & 4.52 & 3.80 & -1.670 & 589 & .095 \\
\hline television & 237. & 3.91 & 3.08 & 354 & 3.25 & 2.27 & 3.008 & 589 & .003 \\
\hline video & 237 & 1.16 & 1.55 & 354 & 70 & 87 & 4.581 & 589 & .000 \\
\hline internet & 237 & 56 & 1.22 & 354 & 41 & 68 & 1.903 & 589 & .058 \\
\hline
\end{tabular}

The results describe that adolescent girls read newspapers and magazines $(p=.006)$ statistically more than adolescent boys. On the other hand adolescent boys view television and video statistically more than adolescent girls $(p=.003)$.

The respondents preferred films (mostly action), entertainment programmes and serials, Table 2 .

Adolescent boys prefer programmes with cognitive character including reports and publicism, documents, but action films, scifi and sport, too. Adolescent girls prefer serials and fairy-tales, Table 3.
Programme structure preferences

Table 2

\begin{tabular}{|c|c|c|c|c|c|}
\hline programine structure & $\mathbf{n}$ & Minimum & Maximum & Mean & SD \\
\hline Reports and publicism & 590 & o & 4 & 2.00 & a 1.06 \\
\hline Films & 590 & o & 7 & 2.93 & 98 \\
\hline - action & 590 & a & 33 & 2.29 & \begin{tabular}{l|l}
9 & 1.75 \\
\end{tabular} \\
\hline - sci-fi (serials) & 591 & d & 4 & 1.74 & $\begin{array}{ll}4 & 1.30 \\
\end{array}$ \\
\hline Serials & 588 & o & 4 & 2.30 & d 1.20 \\
\hline _soap operas" & 591 & a & 33 & 1.62 & 2.20 \\
\hline Sport & 590 & a & 4 & 1.90 & d 1.35 \\
\hline Fairy-tales & 591 & 0 & 23 & 2.04 & $4 \quad 1.44$ \\
\hline Documents & 591 & 0 & 4 & 1.76 & 61.20 \\
\hline Entertainment programmes & 591 & 0 & 6 & 2.35 & 5.111 \\
\hline
\end{tabular}

The differences between boys and girls in depend

Table 3 on preferred programme structure

\begin{tabular}{|c|c|c|c|c|c|c|c|c|c|}
\hline & \multicolumn{3}{|c|}{ boys } & \multicolumn{3}{|c|}{ girls } & \multirow[b]{2}{*}{$t$} & \multirow[b]{2}{*}{ df } & \multirow[b]{2}{*}{$p$} \\
\hline & $\mathrm{n}$ & AM & SD & $\mathrm{n}$ & $\mathrm{AM}$ & SD & & & \\
\hline $\begin{array}{l}\text { programmes with cognitive } \\
\text { character }\end{array}$ & 237 & 2.17 & .93 & 353 & 1.69 & .86 & 6.402 & 588 & .000 \\
\hline $\begin{array}{l}\text { programmes with } \\
\text { entertainment character }\end{array}$ & 233 & 2.17 & .67 & 352 & 2.09 & .57 & 1.502 & 583 & 134 \\
\hline Reports and publicism & 237 & 2.23 & 1.15 & 353 & 1.85 & 98 & 4.338 & 58 & 000 \\
\hline Films & 236 & 2.94 & .98 & 354 & 2.93 & 98 & .121 & 588 & .904 \\
\hline - action & 237 & 2.80 & 2.29 & 353 & 1.95 & 1.14 & 5.928 & 588 & .000 \\
\hline -sci-fi (serials) & 237 & 1.97 & 1.34 & 354 & 1.58 & 1.25 & 3.624 & 589 & .000 \\
\hline Serials & 234 & 1.95 & 1.19 & 354 & 2.54 & 1.15 & -6.027 & \begin{tabular}{|l|}
586 \\
\end{tabular} & .000 \\
\hline - „., soap operas" & 237 & 1.41 & 3.10 & 354 & 1.76 & 1.26 & -1.913 & 589 & .056 \\
\hline Sport & 237 & 2.64 & 1.34 & 353 & 1.40 & 1.11 & 12.249 & 588 & .000 \\
\hline Fairy-tales & 237 & 1.73 & 1.16 & 354 & 2.24 & 1.58 & -4.236 & 589 & .000 \\
\hline Documents & 237 & 2.10 & 1.17 & 354 & 1.53 & 1.16 & 5.819 & 589 & .000 \\
\hline Entertainment programmes & 237 & 2.34 & 1.11 & 354 & 2.36 & 1.11 & -212 & 589 & .832 \\
\hline
\end{tabular}

We divide respondents into A-D types of TV viewers. Graph 1 describes occurrence of the TV viewers types.

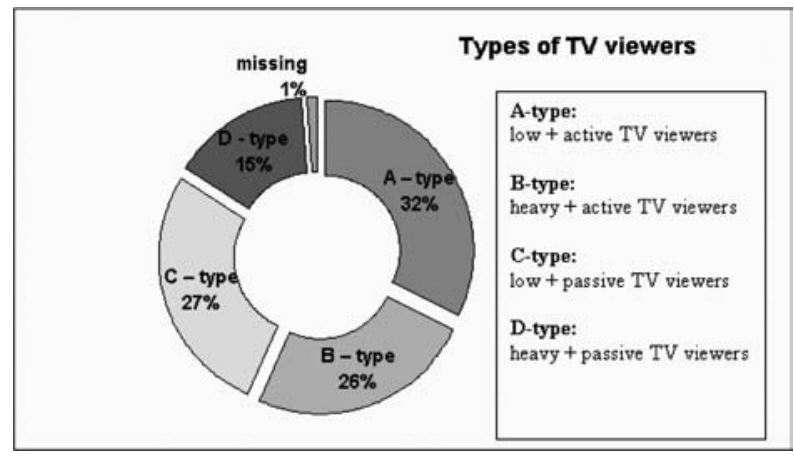

Graph 1 The A-D types of $T V$ viewers; $n=595$

Difference of TV programme types dependent

Table 4 on intensity of TV viewing

\begin{tabular}{|c|c|c|c|c|c|c|c|c|c|}
\hline intensity of TV viewing & & higher & & & lower & & & & \\
\hline TV programmes & $\mathrm{n}$ & AM & SD & $\mathrm{n}$ & $\mathrm{AM}$ & SD & $\mathrm{t}$ & df & $\mathrm{p}$ \\
\hline $\begin{array}{l}\text { programmes with cognitive } \\
\text { character }\end{array}$ & 260 & 1.89 & 97 & 328 & 1.88 & 87 & 026 & 586 & $\begin{array}{r}x \\
\end{array}$ \\
\hline $\begin{array}{l}\text { programmes with } \\
\text { entertainment character }\end{array}$ & 255 & 2.33 & .54 & 328 & 1.96 & .62 & 7.626 & 581 & .000 \\
\hline Reports and publicism & 260 & 2.05 & 1.11 & 328 & 1.97 & 1.03 & 875 & 586 & 382 \\
\hline Films & 259 & 3.11 & .88 & 329 & 2.79 & 1.02 & 4.062 & 586 & .000 \\
\hline - action & 259 & 2.54 & 2.24 & 329 & 2.10 & 1.20 & 3.078 & 586 & .002 \\
\hline - sci-fi (serials) & 260 & 1.90 & 1.34 & 329 & 1.60 & 1.25 & 2.758 & 587 & .006 \\
\hline Serials & 257 & 2.75 & 1.05 & 329 & 1.95 & 1.19 & 8.574 & 584 & .000 \\
\hline -„soap operas" & 260 & 2.17 & 2.96 & 329 & 1.18 & 1.15 & 5.534 & 587 & .000 \\
\hline Sport & 260 & 1.87 & 1.38 & 328 & 1.92 & 1.34 & -485 & 586 & 628 \\
\hline Fairy-tales & 260 & 2.18 & 1.17 & 329 & 1.92 & 1.62 & 2.177 & 587 & .030 \\
\hline Documents & 260 & 1.72 & 1.23 & 329 & 1.79 & 1.17 & -746 & 587 & 456 \\
\hline Entertainment programmes & 260 & 2.51 & 1.08 & 329 & 2.23 & 1.12 & 3.105 & 587 & .002 \\
\hline
\end{tabular}


We supposed that there is a statistical difference between intensity of TV viewing and activity of TV viewers dependent on programme preference, Table 4 and Table 5.

Difference of TV programme types dependent on intensity of activity

\begin{tabular}{|c|c|c|c|c|c|c|c|c|c|}
\hline activity of TV viewers & \multicolumn{3}{|c|}{ active } & \multicolumn{3}{|c|}{ passive } & & & \\
\hline TV programmes & $\mathrm{n}$ & $\mathrm{AM}$ & SD & $\mathrm{n}$ & AM & SD & $t$ & $d f$ & \\
\hline $\begin{array}{l}\text { programmes with cognitive } \\
\text { character }\end{array}$ & 338 & 2.02 & .90 & 252 & 1.70 & 90 & 4.259 & 588 & .000 \\
\hline \begin{tabular}{|l|} 
programmes with \\
entertainment character
\end{tabular} & 334 & 2.21 & .59 & 251 & 2.00 & 62 & 4.268 & 583 & .000 \\
\hline Reports and publicism & 338 & 2.17 & 1.05 & 252 & 1.77 & 1.05 & 4.598 & 58 & .000 \\
\hline Films & 338 & 3.07 & 91 & 252 & 2.74 & 1.03 & 4.107 & 588 & .000 \\
\hline - action & 338 & 2.37 & 2.06 & 252 & 2.18 & 1.20 & 1.309 & 588 & 191 \\
\hline - sci-fi (serials) & 339 & 1.78 & 1.32 & 252 & 1.67 & 1.28 & 1.055 & 589 & .292 \\
\hline Serials & 337 & 2.48 & 1.18 & 251 & 2.07 & 1.19 & 4.193 & 586 & .000 \\
\hline -_soap operas" & 339 & 1.71 & 2.14 & 252 & 1.49 & 2.27 & 1.219 & 589 & .223 \\
\hline Sport & 338 & 1.96 & 1.33 & 252 & 1.81 & 1.38 & 1.411 & 588 & .159 \\
\hline Fairy-tales & 339 & 2.08 & 1.15 & 252 & 1.98 & 1.76 & 828 & 589 & 408 \\
\hline Documents & 339 & 1.86 & 1.19 & 252 & 1.62 & 1.19 & 2415 & 589 & .016 \\
\hline Entertainment programmes & 339 & 2.47 & 1.08 & 252 & 2.19 & 1.13 & 3.103 & 589 & .002 \\
\hline
\end{tabular}

We supposed statistical difference between A-D types of TV viewers and programme preference. The results confirm statistical difference among several types of TV programmes, Table 6 .

The research confirmed possibility of utilization of A-D TV viewers typology. It confirmed practical possibility of utilization of Gerbne's cultivation theory and selective exposure theory (activity of TV viewers)

TV viewers with higher intensity of TV viewing prefer programmes with entertainment character - films including sci-fi, serials including soap operas, fairy-tales and entertainment programmes. Active TV viewers prefer programmes with cognitive and with entertainment character - reports and publicism, documentaries, films and serials and entertainment programmes.

\section{Conclusion}

We describe the main characteristics of A-D types of TV viewers: dents).

A-type of $T V$ viewer (active + low TV viewers; $32 \%$ of respon-

Active looking for new information and experiences is not orientated only to media reality of television. A-type of TV viewer is able to obtain more complex information from reality of the real world. He can supplement them from other information sources (for example newspapers, radio or internet). He is able to keep and improve the quality of real interpersonal relationships. TV viewers of A-type and B-type view more TV programmes of cognitive character including reports and publicism, documentaries than TV viewers of C-type and D-type.

B-type of TV viewer (active + heavy TV viewers; $26 \%$ of respondents).

TV viewers of B-type and TV viewers of A-type prefer TV programmes of cognitive character including reports and publicism,
ANOVA analysis of TV programme types

Table 6 depend on types of TV viewers

\begin{tabular}{|c|c|c|c|c|c|c|}
\hline & & Sum of Squares & df I I & Mean Square & F & Sig. \\
\hline \multirow{3}{*}{$\begin{array}{l}\text { programmes with } \\
\text { coguitive character }\end{array}$} & between groups & 14.555 & 3 & 4.852 & 5.950 & .001 \\
\hline & within groups & 476.215 & 584 & 815 & & \\
\hline & total & 490.770 & 587 & & & \\
\hline \multirow{3}{*}{$\begin{array}{l}\text { programmes with } \\
\text { entertainment } \\
\text { character }\end{array}$} & between groups & 24.890 & 3 & 8.297 & 24.919 & .000 \\
\hline & within groups & 192.774 & 579 & .333 & & \\
\hline & total & 217.664 & 582 & & & \\
\hline \multirow[t]{3}{*}{ Reports and publicism } & between groups & 24.359 & 3 & 8.120 & 7.391 & 000 \\
\hline & within groups & 641.613 & 584 & 1.099 & & \\
\hline & total & 665.973 & 587 & & & \\
\hline \multirow[t]{3}{*}{ Films } & between groups & 28.744 & 3) & 9.581 & 10.570 & .000 \\
\hline & within groups & 529.397 & 584 & 907 & & \\
\hline & total & 558.141 & 587 & & & \\
\hline \multirow[t]{3}{*}{ Action film } & between groups: & 43.645 & 3 & 14.548 & 4.866 & .002 \\
\hline & within groups & 1746.042 & 584 & 2.990 & & \\
\hline & total & 1789.687 & 587 & & & \\
\hline \multirow[t]{3}{*}{ Sci-fi } & between groups & 12.771 & 3 & 4.257 & 2.552 & .055 \\
\hline & within groups & 975.911 & 585 & 1.668 & & \\
\hline & total & 988.683 & 588 & & & \\
\hline \multirow[t]{3}{*}{ Serials } & between groups & 97.757 & 3 & 32.586 & 25.567 & .000 \\
\hline & within groups & 741.780 & 582 & 1.275 & & \\
\hline & total & 839.538 & 585 & & & \\
\hline \multirow[t]{3}{*}{ Soap operas } & between groups & 153.782 & 3 & 51.261 & 11.132 & .000 \\
\hline & within groups & 2693.733 & 585 & 4.605 & & \\
\hline & total & 2847.514 & 588 & & & \\
\hline \multirow[t]{3}{*}{ Sport } & between groups & 2825 & & 942 & 512 & 674 \\
\hline & within groups & 1074.255 & 584 & 1.839 & & \\
\hline & total & 1077.080 & 587 & & & \\
\hline \multirow[t]{3}{*}{ Fairy-tales } & between groups & 17.525 & 3 & 5.842 & 2.832 & .038 \\
\hline & within groups & 1206.726 & 585 & 2.063 & & \\
\hline & total & 1224.251 & 588 & & & \\
\hline \multirow[t]{3}{*}{ Documents } & between groups & 9.081 & 3 & 3.027 & 2.128 & .096 \\
\hline & within groups & 832.166 & 585 & 1.423 & & \\
\hline & total & 841.246 & 588 & & & \\
\hline \multirow{3}{*}{$\begin{array}{l}\text { Entertainment } \\
\text { programmes }\end{array}$} & between groups & 18.819 & 3 & 6.273 & 5.215 & .001 \\
\hline & within groups & 703.727 & 585 & 1.203 & & \\
\hline & total & 722.547 & 588 & & & \\
\hline
\end{tabular}

documentaries than TV viewers of C-type and D-type. On the other hand they view programmes of entertainment character, especially action films more than TV viewers of other A-D types. They prefer serials including soap operas and fairy-tales, too. We understand their preference of programme of cognitive and entertainment character as ambiguous.

C-type of TV viewer (passive + low TV viewers; $27 \%$ of respondents).

TV viewers of C-type and TV viewers of D-type view less programmes of cognitive character including reports and publicism, documentaries than TV viewers of A-type and TV viewers of Btype. TV viewers of C-type view serials including soap operas less than TV viewers of B-type and D-type. They do not prefer films, either.

D-type of TV viewer (passive + heavy TV viewers; $15 \%$ of respondents).

TV viewers of D-type cannot be oriented in flood of information and utilize it. TV viewers of D-type don't prefer (like TV viewers of C-type) TV programmes of cognitive character. They prefer (like TV viewers of B-type) serials including soap operas.

We emphasize prevention to frequent and passive TV viewing, prevention to dependence on television (or excessive television viewing) and finally prevention to uncritical watching the television (Kotrč, 2005). It's effectiveness depends on parallel effort of parents, school, and mass media. 


\section{References:}

[1] DOMINICK, J. R.: The dynamics of mass communication, McGraw Hill, New York 1993

[2] INNES, J. M., ZEITZ, H.: The Public's View of The Impact of The Mass Media: A Test of The 'Third person's Effect', European Journal of Social Psychology, 18, 5/1988, pp. 457-463

[3] JANOUŠEK, J., SLAMĚNÍK, I.: A Man and media: Psychology of mass comunication, J. Výrost, I. Slaměník (Eds.): Applied social psychology I., Portál, Praha, 1998

[4] KOTRČ, D.: The influence of television on form of adolescent identity, Diploma Thesis, Faculty of the Humanities, Trnavska univerzita, Trnava, 1999

[5] KOTRČ, D.: The selection and processing of media reality information in relation to personality attributes of adolescent viewers, Dissertation thesis, Faculty of philosophy, Trnavska univerzita, Trnava, 2005

[6] LITTLEJOHN, S. W.: Theories of Human Communication, 4. vyd., Wadsworth Publishing Company, Belmont, 1992.

[7] LIVINGSTONE, S. M.: Making Sense of Television (The psychology of Audience Interpretation), Pergamon Press, Oxford, 1990

[8] LOWERY, S. A., DE FLEUR, M. L.: Milestones in Mass Communication Research, 2. vyd. Longman, New York, 1988

[9] MCQUAIL, D.: The introduction to theory of mass communication, Portal, Praha, 1999

[10] MIKULÁŠTÍK, M.: Communication abilities in practice, Grada Publishing, Praha, 2003

[11] NOCIAR, A.: The comparison of ESPAD researches in Slovakia between 1995-1999, Asklepios, Bratislava, 2000. 